\title{
The Role of the Student in the English to Speakers of Other Languages Learning Process
}

\author{
Maria José Lisboa Antunes \\ Instituto Politécnico de Viseu
}

\begin{abstract}
:
This study main objective is to analyse the role of the student during the learning process of a foreign language. For this we did a needs analysis to students of the higher education level and further on we analysed the data that we collected in order to understand how to increase the student's ability to communicate in a foreign language, more specifically in English. The methodology used, needs analysis, allowed us to assess the students' necessities in this area of expertise and, later on, to implement new strategies and use new materials in the classroom so their needs might be fulfilled and our goals might be achieved.

This paper is divided into four parts, in the first one we present the theoretical framework, in the second one we focused on the methodology used, which was a needs analysis, in the third we show the results and in the fourth one we present the main conclusions of this study and its limitations. With this paper we came up to some relevant developments and progresses in what concerns the importance of the student's attitude during the learning process of a foreign language.
\end{abstract}

Keywords: Teaching English to Speakers of Other Languages (TESOL), English for Specific Purposes (ESP), English for Tourism, Needs Analysis (NA). 